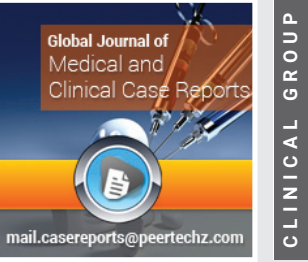

\section{Renal infarction due to}

\section{ascending aortic thrombus: $\mathrm{A}$}

\section{case report}

\author{
Beliz Oztok Tekten ${ }^{1 *}$ and Mustafa Hizal ${ }^{2}$ \\ ${ }^{1}$ Assistant Professor, Department of Emergency Medicine, Bolu Abant Izzet Baysal University, Faculty \\ of Medicine, Turkey \\ ${ }^{2}$ Assistant Professor, Department of Radiology, Bolu Abant Izzet Baysal University, Faculty of \\ Medicine, Turkey
}

Received: 08 October, 2020

Accepted: 20 October, 2020

Published: 21 October, 2020

*Corresponding author: Beliz Oztok Tekten, Assistant Professor, Department of Emergency Medicine, Bolu Abant Izzet Baysal University, Faculty of Medicine, Turkey, Tel: + 9037425410 00; Fax: +90 37425345 06; E-mail: belizoztok@gmail.com

ORCID: https://orcid.org/0000-0002-4007-005X

Keywords: Ascending aortic thrombus; Acute renal infarction; Emergency department

https://www.peertechz.com

Check for updates

\title{
Abstract
}

Ascending aortic thrombus is a rare condition that is fatal due to its complications [1]. In this case report, we aim to present a case of renal infarction due to ascending aortic thrombus. A 71-year-old male patient was admitted to the emergency department with chest pain and right-side pain. Physical examination revealed tenderness in the right flank. Thoracic Computed Tomography (CT) angiography was performed, and ascending aortic thrombus and focal parenchymal infarction area in the right kidney were observed in abdominal sections included in the examination.

\section{Introduction}

Thromboembolic diseases of the aorta occur as a result of the atherosclerotic process. Plaques that develop due to lipid accumulation in the intima and media layers of the aorta transform into secondary inflammation, fibrous tissue accumulation, and surface erosion. Thrombus may result in thrombotic or atherosclerotic embolism [1].

Thromboembolism usually leads to occlusion of the middle and large arteries, resulting in stroke, transient ischemic attack, renal infarction, and peripheral thromboembolism. Atherosclerotic embolisms cause occlusion of the small arteries and arterioles, resulting in renal failure, blue finger syndrome, and mesenteric ischemia [1].

Risk factors for thromboembolic diseases of the aorta are age, gender, hypertension, diabetes mellitus, hypercholesterolemia, sedentary lifestyle, and smoking; these are common risk factors for other vascular diseases. In addition, several factors are associated with arterial thrombus, including atherosclerosis, malignant tumors, factor $\mathrm{V}$ Leiden mutation, and protein S deficiency [2].

In this case report, we aim to present a case of renal infarction due to ascending aortic thrombus.

\section{Case report}

A 71-year-old male patient was admitted to the emergency department with complaints of chest pain and right-side pain for 2 days. Patient anamnesis revealed that chest pain often occurred with exertion, taking rest resulted in partial relief, but side pain was continuous, severe, and the use of analgesics showed no effect. The patient had hypertension, diabetes mellitus, and coronary artery disease and used acetylsalicylic acid, $\mathrm{Ca}^{2+}$ channel blocker, and oral antidiabetic.

Physical examination revealed; blood pressure: 130/65 $\mathrm{mmHg}$, heart rate: $92 / \mathrm{min}$, and sensitivity in the right flank area. No abnormality was observed in other systems. Electrocardiogram revealed $\mathrm{T}$ wave inversion and ST segment depression $(<1 \mathrm{~mm})$ in anterior leads $(\mathrm{V} 1-4)$. Transthoracic echocardiography was performed with the preliminary diagnosis of acute coronary syndrome. No diagnostic acute finding was found. The patient's laboratory evaluation upon admission; Glomerular filtration rate (GFR): 90,8 ml/dak/1.73 m2, Urea: $32 \mathrm{mg} / \mathrm{dl}$ Creatinine: $0,7 \mathrm{mg} / \mathrm{dl}$.

Thoracic angiogram Computed Tomography (CT) was performed to exclude aortic dissection. CT results revealed ascending aortic thrombus and focal parenchymal infarction 
area in the right kidney in the abdominal sections included in the CT field [Figures 1-4].

The patient was advised cardiovascular surgery. Because of systemic and peripheral thromboembolism risk, the operation and interventional procedures were not included in the treatment plan. Anticoagulant treatment was decided, and the patient was heparinized in the emergency room, heparinization therapy was initiated with enoxaparin $1 \mathrm{mg} / \mathrm{kg}$.

Patient was then transferred to the intensive care unit for thrombolytic therapy. Recombinant tissue-type plasminogen activator (rtPA), $100 \mathrm{mg}$, over 2 hours, intravenous infusion was preferred.

On the fifth day of the treatment we have seen the thrombus resolution via thoracic angiogram CT. As the patient's physical examination and vital parametres were normal, he was discharged with medical treatment, acetyl salicylic acid $100 \mathrm{mg}$ and rivaroksaban $20 \mathrm{mg} /$ per day.

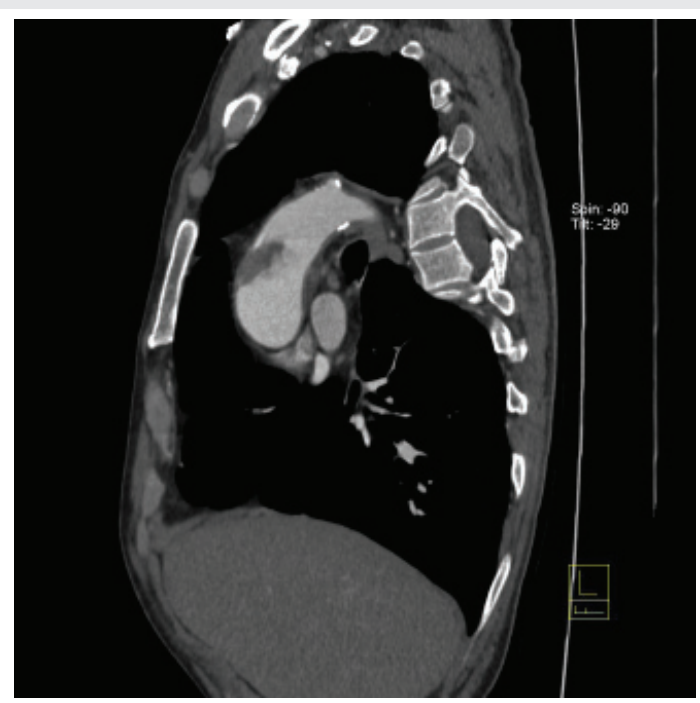

Figure 1: Ascending aortic thrombus, thoracic CT angiography sagittal section.

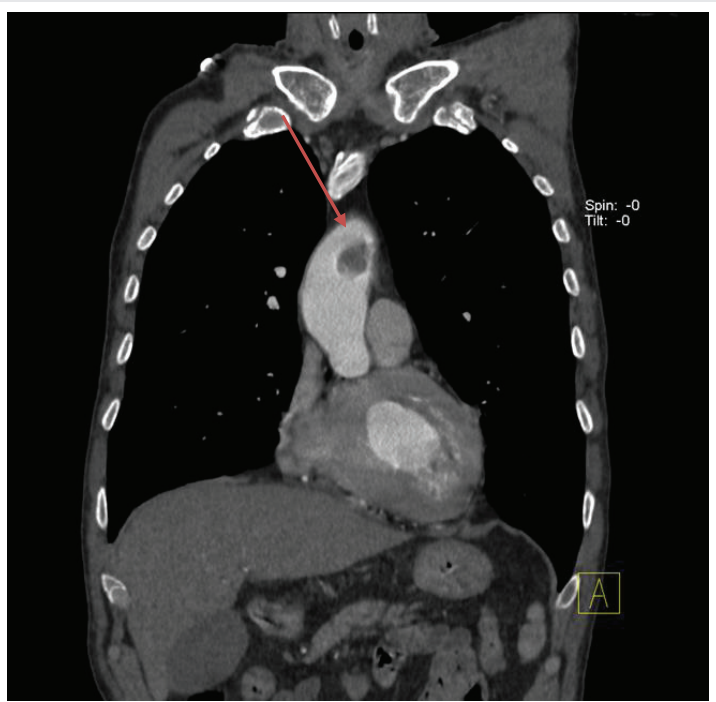

Figure 2: Ascending aortic thrombus, thoracic CT angiography coronal section.
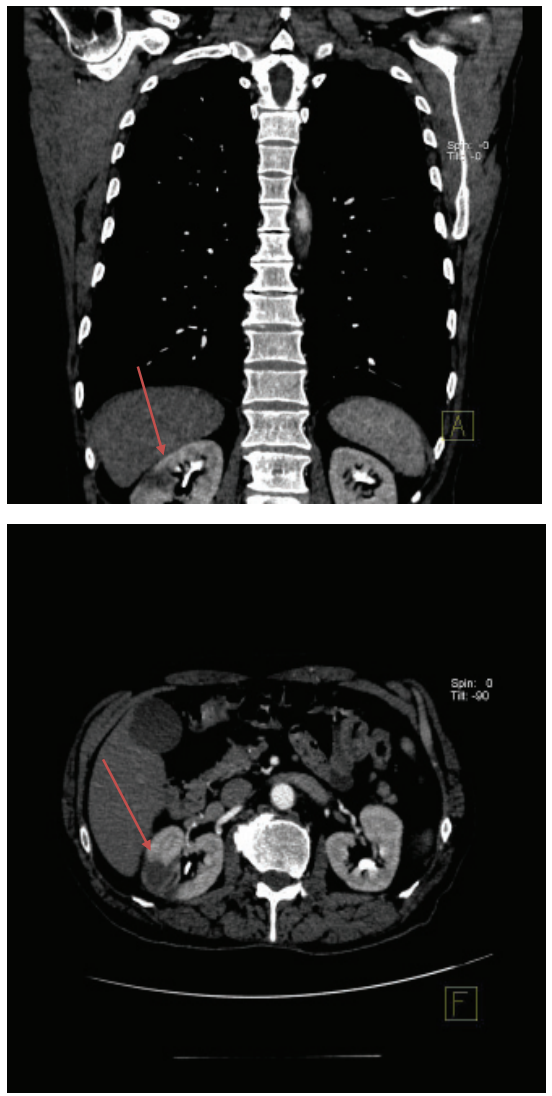

Figures 3,4: Right renal parenchymal infarction area.

\section{Discussion}

Ascending aortic thrombus is usually incidentally diagnosed and sporadic cases have been reported in the literature [3]. Hypercoagulopathy, smoking, steroid use, trauma, substance dependence, rheumatic diseases, primary endothelial diseases, and vasculitis are the etiological factors. The thromboembolic disease of aorta has been known as a result of atherosclerosis, in the absence of hypercoagulopathy. Therefore, we emphasized the risk factors of atherosclerosis as the risk factors of ascending aortic thrombus. In our case, the patient had hypertension, diabetes mellitus, and coronary artery disease. The presence of all these diseases indicates that the thrombus formation has been developed due to atherosclerosis in this case. And also as the patient hasn't undergo surgery, we couldn't have pathological examination of the thrombus [4].

Aortic thrombi can cause non-cardiogenic peripheral thromboembolism, such as cerebral embolism, acute myocardial infarction or bowel ischemia [1,2,4]. Meyermann, et al. reported that descending aortic thrombosis has been diagnosed after a peripheral embolic event in most cases, similarly to ascending aortic thrombus. Differently to ascending aortic thrombus, approximately $50 \%$ of the cases presented with extremity emboli.

Aortic thrombi are frequently found in the descending aorta (37.5\%), and ascending aortic thrombi have been less frequently reported $[2,3,4]$. 
Although the European Society of Cardiology (ESC) 2014 Guidelines for the Diagnosis and Treatment of Aortic Diseases mentions surgical approach and interventional treatment as part of the treatment strategy for thromboembolic diseases of the aorta, the emphasis is on antiplatelet and anticoagulant therapies. The presence of comorbidity and complications poses a high risk for surgical intervention and increases morbidity and mortality rates. The risk of complications is high especially in atypically located and large thrombi [5].

Anticoagulant or antiplatelet therapy are suggested [6] and should be preferred in patients with peripheral embolism or stroke [7]. One of these treatment strategies should be chosen based on comorbidity and other indications. In the present case, anticoagulant therapy was selected and successful thrombus resolution was achieved.

\section{Conclusion}

We presented a case of ascending aortic thrombus complicated by renal infarction. There are several cases in the literature treated with surgical and interventional treatments. Anticoagulant and thrombolytic therapy was chosen in the present case, and successful thrombus resolution was achieved.

However, we think that there is a need for studies that compare the long-term results of antithrombotic therapy with interventional and surgical treatments.

\section{References}

1. Erbel R, Aboyans V, Boileau C, Bossone E, Bartolomeo RD, et al. (2014) 2014 ESC Guidelines on the diagnosis and treatment of aortic diseases: Document covering acute and chronic aortic diseases of the thoracic and abdominal aorta of the adult. The Task Force for the Diagnosis and Treatment of Aortic Diseases of the European Society of Cardiology (ESC). Eur Heart J 35: 2873 2926. Link: https://bit.ly/3m7Vf5N

2. Li HD, Sun TC (2015) Bowel ischemia caused by a giant thrombus in the ascending aorta. A case report. Vascular 23: 641-644. Link: https://bit.ly/3m792d9

3. Soo A, Marley D, McGrath-Soo L, Herron B, Parissis H (2014) Ascending aorta thrombus: A diagnostic and treatment dilemma. Asian Cardiovasc Thorac Ann 22: 731-733. Link: https://bit.ly/2HneQzP

4. Meyermann K, Trani J, Caputo FJ, Lombardi JV (2017) Descending thoracic aortic mural thrombus presentation and treatment strategies. J Vasc Surg 66 : 931-936. Link: https://bit.ly/2TbIH18

5. Maloberti A, Oliva F, De Chiara B, Giannattasio C (2016) Asymptomatic aortic mural thrombus in a minimally atherosclerotic vessel. Interact Cardiovasc Thorac Surg 22: 371-374. Link: https://bit.ly/2T6paiB

6. Sabetai MM, Conway AM, Hallward G, Bapat V (2013) Ascending aorta thrombus adjacent to a cholesterol-rich plaque as the source of multiple emboli. Interact Cardiovasc Thorac Surg 16: 389-390. Link: https://bit.ly/3o9u6By

7. Maat GE, Vigano G, Mariani MA, Natour E (2017) Catching a floating thrombus a case report on the treatment of a large thrombus in the ascending aorta. $J$ Cardiothorac Surgery 12: 34. Link: https://bit.ly/3kdOLID
Discover a bigger Impact and Visibility of your article publication with

Peertechz Publications
Highlights

* Signatory publisher of ORCID

* Signatory Publisher of DORA (San Francisco Declaration on Research Assessment)

* Articles archived in worlds' renowned service providers such as Portico, CNKI, AGRIS, TDNet, Base (Bielefeld University Library), CrossRef, Scilit, J-Gate etc.

* Journals indexed in ICMJE, SHERPA/ROMEO, Google Scholar etc.

- OAI-PMH (Open Archives Initiative Protocol for Metadata Harvesting)

* Dedicated Editorial Board for every journal

Accurate and rapid peer-review process

Increased citations of published articles through promotions

* Reduced timeline for article publication

Submit your articles and experience a new surge in publication services (https://www.peertechz.com/submission).

Peertechz journals wishes everlasting success in your every endeavours.

Copyright: @ 2020 Tekten BO, et al. This is an open-access article distributed under the terms of the Creative Commons Attribution License, which permits unrestricted use distribution, and reproduction in any medium, provided the original author and source are credited.

Citation: Tekten BO, Hizal M (2020) Renal infarction due to ascending aortic thrombus: A case report. Glob J Medical Clin Case Rep 7(2): 078-080 